Matthias Wanner, Annaliesa Hilger, Janina Westerkowski, Michael Rose, Franziska Stelzer, Niko Schäpke

\title{
Towards a Cyclical Concept of Real-World Laboratories
}

A Transdisciplinary Research Practice for Sustainability Transitions

Originally published in:

disP - The Planning Review,

54 (2018), 94-114

DOI: $10.1080 / 02513625.2018 .1487651$ 
Matthias Wanner $a, b$, *

Annaliesa Hilger $b$

Janina Westerkowski b

Michael Rose b

Franziska Stelzer a

Niko Schäpke c

\section{Towards a Cyclical Concept of Real- World Laboratories}

\section{A Transdisciplinary Research Practice for Sustainability Transitions}

a Wuppertal Institute, Wuppertal, Germany

b University of Wuppertal, Germany

c Leuphana University, Lüneburg, Germany

* Corresponding author:

Matthias Wanner

Wuppertal Institut für Klima, Umwelt, Energie gGmbH

Döppersberg 19

42103 Wuppertal

Germany

E-mail: matthias.wanner@wupperinst.org

Phone: +49 202 747564-23

Fax: +49 202 2492-108

This is the author's version of a work that was accepted for publication. Changes resulting from the publishing process, such as editing, corrections and structural formatting, may not be reflected in this document. Changes may have been made to this work since it was submitted for publication. A definitive version was subsequently published in the Journal cited above. 


\title{
Towards a Cyclical Concept of Real-World Laboratories
}

\section{A Transdisciplinary Research Practice for Sustainability Transitions}

\author{
Matthias Wanner ${ }^{1,2}$, Annaliesa Hilger ${ }^{1}$, Janina Westerkowski ${ }^{1}$, Michael Rose ${ }^{1}$, Franziska Stelzer ${ }^{2}$, Niko Schäpke ${ }^{3}$ \\ ${ }^{1}$ TransZent - Center for Transformation Research and Sustainability, University Wuppertal, Doeppersberg 19, \\ 42103 Wuppertal, Germany \\ ${ }^{2}$ Wuppertal Institute for Climate, Environment and Energy, Doeppersberg 19, 42103 Wuppertal, Germany \\ ${ }^{3}$ IETSR - Institute for Ethics and Transdisciplinary Sustainability Research, Faculty Sustainability, Leuphana \\ University Lüneburg, Scharnhorststr. 1, 21335 Lüneburg, Germany
}

\begin{abstract}
The transformative research approach of Real-World Laboratories (RWL) has recently attracted attention in German sustainability science. Some definitions and understandings have been published, but guidelines and procedural quality criteria for establishing and running a RWL are still missing. To address this gap, this article has two aims. First it aims to derive key components of RWLS from the current discourse on RWLs and similar, yet more elaborated research approaches. Second, it aims to transfer these key components into a comprehensive research practice. This practice is illustrated by a RWL process in the project "Well-being Transformation Wuppertal" (WTW).

Methodologically, the article builds on a review of RWL-related approaches for collaborative, intervention-oriented research. This includes transition management, transdisciplinary process models and action research. Based on this review, eight key components for RWLs are proposed. They position RWLs as a normatively framed approach that aims to contribute to local action for sustainable development and the empowerment of change agents. The approach uses transdisciplinary methods of knowledge integration and engages in cyclical real-world interventions within certain spatial and content-related boundaries.

The components are transferred into a flowchart, detailing process steps, aims, responsibilities and overall principles for putting RWLs into practice. Thus, a hitherto missing tool for designing and running RWLs is provided. Then, the RWL in district Mirke, Wuppertal, is used as an empirical example to illustrate the application of the flowchart and related key components. Consecutive discussions centre on the different roles of researchers and practitioners in the research process, as well as the relevance of an underlying theory of change for effective interventions. Finally, critical reflection, application and amendment of the proposed flowchart are encouraged.
\end{abstract}




\section{Introduction: Real-World Laboratories - definitions and open questions}

Reflecting the role of science in the current age of uncertainty and complexity, appropriate formats of meaningful research for societal transformation have been discussed by researchers, as well as by promoters of sustainability science (Gibbons et al., 1994; Nowotny, Scott, \& Gibbons, 2001; Raskin et al., 2002; Reid et al., 2010; Schneidewind, Singer-Brodowski, Augenstein, \& Stelzer, 2016; WBGU, 2011). Despite conceptual and methodological differences, all agree on the need for science to produce robust knowledge to solve real-world environmental and social problems. Proposed formats of interdisciplinary and transdisciplinary (TD) research frequently integrate scientific with nonscientific knowledge.

One of the latest approaches of this kind is called Real-World Laboratory (RWL, German Reallabor). This has gained considerable attention, particularly in the German-speaking sustainability science community (De Flander et al., 2014a; Jahn \& Keil, 2016; MWK, 2013; Schäpke et al., 2017; Schäpke, Singer-Brodowski, Stelzer, Bergmann, \& Lang, 2015a; Schäpke, Stelzer, Bergmann, \& Lang, 2016; Schneidewind, 2014; Schneidewind \& Scheck, 2013; Schneidewind, Singer-Brodowski, Augenstein, \& Stelzer, 2016; Wagner \& Ertner, 2016; Wagner \& Grunwald, 2015). Although its conceptual and methodological approach has only been shaped roughly (MWK, 2013; Schneidewind \& Scheck, 2013), the acceptance of RWL in public calls for bids and funding schemes has been remarkable. The Ministry of Science, Research and Art in the German state of Baden-Württemberg has recently launched two special RWL funding schemes for urban and regional sustainability transformation (Wagner \& Ertner, 2016). Multiple national calls (e. g. the funding initiatives "Sustainable Economy" and "Zukunftsstadt/Future Cities" by the German Federal Ministry of Education and Research) are encouraging research teams to install RWLs, mostly on an urban level. Urban transition experiments and urban living labs are also asked for by the Joint Programme Initiative for Urban Europe in their calls since 2013.

Initial definitions and understandings of RWLs published since 2013 include that of the "Science for Sustainability" expert group established by Baden-Württemberg's Ministry for Science, Research and Art (Schäpke, Singer-Brodowski, Stelzer, Bergmann, \& Lang, 2015b). They defined six requirements for successful RWLs, focusing on inter- and transdisciplinarity (especially involving civil society) and long-term reflexive projects (MWK, 2013, p. 30). Further methodological stipulations were not determined, nor was any kind of "real-world experiment" or "intervention" mentioned. A second short definition of RWLs (wrongly translated as Living Labs) was published by the German Advisory Council on Global Change (WBGU). It focused on the idea of an "experimental turn" in the social sciences promoting "real-life experiments" in order "to learn about social dynamics and processes" (WBGU, 2014, p. 88). This definition did not mention inter- or transdisciplinarity, but identified researchers and "transformative science" as the main producers of "socially robust knowledge" (ibid.). A third, more comprehensive understanding has been provided by the WBGU in their latest report on city transformation (WBGU, 2016). This definition mentions key components of RWLs: realworld problems as a starting point, strong collaborative interactions between science and practice, links to transdisciplinary sustainability research, diverse intervention formats, and the production of systems, target and transformation knowledge. Furthermore it identifies core features of the role of researchers and practitioners: "In this constellation, researchers contribute to the project their 
scientific knowledge, their methodological expertise, and an ability to reflect and evaluate which, compared to practitioners, is disengaged from praxis. The practitioners, in turn, contribute experience and know-how" (WBGU, 2016a, p. 512). Moreover, the WBGU locates RWLs especially in urban areas like "townships, city districts or neighbourhoods" (ibid.). It is unclear, however, whether this localisation is due to the city-focused nature of the report or is considered a general feature.

Going beyond mere definitions, some texts have been published framing RWLs normatively as attractive and powerful formats of a "transformative science" which focuses on collaborative realworld change and systems innovation (Schäpke, Stelzer, Bergmann, Singer-Brodowski, et al., 2017; Schneidewind \& Scheck, 2013; Schneidewind \& Singer-Brodowski, 2013, p. 124ff). As an interim result of an ongoing RWL project in the city of Karlsruhe, five constituting criteria for RWLs have been proposed: (1) normativity (sustainable development as a guiding principle), (2) transdisciplinarity (science-society interface), (3) transformativity (hybrid endeavour aiming at societal transformation and scientific insights), (4) civic orientation (inclusion of citizens from the very beginning), and (5) long-term research setting (providing a framework and infrastructure for real-world experiments) (Parodi et al., 2016).

\section{Box 1: Reflections on a catchy but contradictory term}

The most popular idea of a "laboratory" is a sterile, white room where scientists carry out experiments. Accordingly, the classic concept defines laboratories by their exact set-up and clear boundaries between inside and outside (Guggenheim, 2012, p. 101). The setting and processes are as fully controlled as possible; the "real" outside world with all its complexity, contamination and randomness is shut out. Opening the doors of such a highly-organised setting to let in life's fuzziness ruins all the efforts undertaken to separate causality from chance. Conversely, applying "laboratory" methods to cooperative, real-world field research seems to harbour ethically alarming aspects like using people as "laboratory rats".

This is contradicted, however, by the recent advent of a bundle of creativity-driven "lab" projects that cultivate co-creation as a way to enrich and enhance our real world (Berkhout et al., 2010; Blikstein \& Krannich, 2013; Feola \& Nunes, 2014; Gershenfeld, 2012; Seyfang \& Haxeltine, 2012; Seyfang \& Smith, 2006; Wieczorek, Raven, \& Berkhout, 2015). Here, the term "lab" is used in the sense of a "shared working space" in which there is no harsh distinction between inside and outside, a place where one starts reconstructing, innovating and inspiring one's surroundings in a practical manner.

The RWL research approach seeks to bridge the extremes of classical scientific experiment ("placeless research", (see Kohler (2008, p. 766) and a "just-do-it" workshop mentality (e.g. creative labs). RWLs are always embedded in a real-world context with real (sustainability) problems to be solved and hence contrast with the objectifying concept of laboratories mentioned above. All in all, we propose that RWLs draw their terminological power and catchiness from the (linguistic) promise of combining the value of concrete action paired with scientific rigour and persuasiveness. In our experience, the term is acceptable to practitioners and helps to establish stable science-practice teams. 
Wagner and Grunwald (2015) flag numerous open issues in the development of RWLs as research approaches. First, the relation between RWLs and established methods of (transdisciplinary) sustainability research should be clarified (see as well Jahn and Keil (2016). Second, the concrete role of science is called into question, as it may range from accompanying and reflecting on research to intervening actively in the RWL process (Wagner \& Grunwald, 2015, p. 29). Thirdly the authors call for a better characterisation of (and criteria for) RWLs in order to avoid arbitrariness. As a way forward, they propose a combination of theoretically driven and empirically grounded development of the concept (ibid. 2015, p. 30).

As the term and concept of RWLs is still new and vague, many definitions and understandings of RWLs are not yet sufficiently clear-cut and applicable, but mixed with hopeful expectations and recommendations. Hence, an empirically applicable and theoretically informed conceptualisation of RWLs remains to be developed.

Addressing this gap, the article focuses on two guiding questions: First, which key components can be derived from existing definitions and understandings of RWLs as well as similar approaches that are already more elaborated? Second, how can these key components be transferred into a comprehensive research practice?

To answer these questions, we proceed as follows. We build on the definitions and understandings of RWLs as discussed in the introduction (ch. 1). Consecutively we provide a comparative overview of established and RWL-related approaches in participatory, transformative and transdisciplinary research (ch. 2). Building on chapter 1 and 2, we develop our understanding of key components of RWLs (ch. 3). These components are then employed to develop a comprehensive flowchart for putting the RWL research approach into practice. The flowchart pinpoints concrete, applicable steps and the roles of participating parties (ch. 4). The application of this concept is then illustrated with a concrete district RWL which is part of the research project "Well-being Transformation Wuppertal (WTW)" (ch. 5). The paper closes with a discussion (ch. 6) and conclusion (ch. 7).

\section{Current research approaches in participatory real-world interaction}

According to Beecroft and Parodi (2016), RWLs draw heavily on research traditions of transdisciplinary, sustainability research and transformative research. Thus, these traditions offer learning potentials to identify and further develop the key components of the RWL approach. We explore them - as represented in particular research approaches - to enrich current RWL understandings. This will help us to transfer our RWL key components into a comprehensive concept of an applicable RWL research process in the next step.

In consideration of the RWL literature mentioned above, the following criteria guide the selection of related approaches:

- the approach should be transdisciplinary and/or participatory/co-creational,

- actively engage in or thoroughly reflect on societal change or real-world "experimentation"

- and/or have a normative standpoint towards sustainable development.

The spectrum of identified approaches ranges from intervention research at the University of Klagenfurt/Austria, through (participatory) action research - which has a long history in social 
sciences and social psychology - transdisciplinary processes and case studies (for instance at ETH Zurich/Switzerland), to the urban transition labs (originally) of the University of Rotterdam/Netherlands. The approaches surveyed here also include the so-called real-world experiment approach. The real-world experiment approach analyses large-scale "experiments" in society ex-post and aims for a recursive and institutionalised learning to deal with uncertainty of knowledge (Gross, Hoffmann-Riem, \& Krohn, 2005, p. 15; 210). Although different from the other approaches as it does not involve transdisciplinary or co-creation, we do include the approach because of its importance for understanding real-world experimentation.

Focusing on key publications on selected approaches, we analyse these according to eight criteria (from a to h) presented in the first column of Table 1. 
Table 1: Comparison of current research approaches in participatory real-world interaction according to selected criteria

\begin{tabular}{|c|c|c|c|c|c|c|c|}
\hline $\begin{array}{l}\text { (Transdisciplinary) } \\
\text { approaches } \\
\text { / analysis criteria }\end{array}$ & $\begin{array}{l}\text { 1. Intervention Research } \\
\text { (Krainer \& Lerchster, 2012b) }\end{array}$ & $\begin{array}{l}\text { 2. Participatory Action } \\
\text { Research } \\
\text { (Cornwall \& Jewkins, 1995; } \\
\text { Kemmis \& McTaggart, 2000; } \\
\text { Ozanne \& Saatcioglu, 2008) }\end{array}$ & $\begin{array}{l}\text { 3. Transdisciplinary Processes } \\
\text { (Scholz, 2011; Scholz, Lang, } \\
\text { Wiek, Walter, \& Stauffacher, } \\
\text { 2006; Scholz \& Tietje, 2002) }\end{array}$ & $\begin{array}{l}\text { 4. Conceptual Model of } \\
\text { Transdisciplinary } \\
\text { (Jahn et al., 2012; Lang et al., } \\
\text { 2012) }\end{array}$ & $\begin{array}{l}\text { 5. Urban Transition Labs (UTL) } \\
\text { \& Transition Magnagement } \\
\text { (Nevens et al., 2013; Nevens \& } \\
\text { Roorda, 2014; Voß, Bauknecht, } \\
\text { \& Kemp, 2006) }\end{array}$ & $\begin{array}{l}\text { 6. Sustainable Living Labs } \\
\text { (Geibler et al., 2013; Liedtke et } \\
\text { al., 2015) }\end{array}$ & $\begin{array}{l}\text { 7. Real-World Experiment } \\
\text { (Groß, Hoffmann-Riem, \& } \\
\text { Krohn, 2005) }\end{array}$ \\
\hline $\begin{array}{l}\text { a) Theoretical } \\
\text { foundation }\end{array}$ & $\begin{array}{l}\text { Enlightenment; qual. social } \\
\text { research; group dynamics; } \\
\text { phenomenol. methods, action } \\
\text { research, TD research }\end{array}$ & $\begin{array}{l}\text { Psychology, qualitative social } \\
\text { research, group dynamics, } \\
\text { organisational development }\end{array}$ & $\begin{array}{l}\text { Human-envir. system (HES), } \\
\text { based on biology, psychology, } \\
\text { industrial ecology, economics } \\
\text { and sociology }\end{array}$ & $\begin{array}{l}\text { Post-normal science and Mode } \\
\text { 2-science; TD is a research } \\
\text { approach, not a theory, } \\
\text { methodology or institution }\end{array}$ & $\begin{array}{l}\text { Multi-level perspective (MLP) } \\
\text { within the framework of transition } \\
\text { management (governance } \\
\text { approach) }\end{array}$ & $\begin{array}{l}\text { (Social) innovation theory; } \\
\text { transition research; social } \\
\text { practice theory }\end{array}$ & $\begin{array}{l}\text { Sociology of scientific knowledge } \\
\text { and uncertainty }\end{array}$ \\
\hline $\begin{array}{l}\text { b) Key terms/ } \\
\text { concepts }\end{array}$ & $\begin{array}{l}\text { Feedback and reaction session; } \\
\text { Self-controlling; Irritation; Self- } \\
\text { reflection }\end{array}$ & $\begin{array}{l}\text { Participation; Power relations; } \\
\text { Empowerment; Capacity Building }\end{array}$ & $\begin{array}{l}\text { Case Study; Knowledge } \\
\text { Integration; Joint Problem } \\
\text { Definition; Mutual Learning }\end{array}$ & $\begin{array}{l}\text { Prob. Transformation; Td } \\
\text { Integration (epistemic, soc.- } \\
\text { organisation and } \\
\text { communication); }\end{array}$ & $\begin{array}{l}\text { Niche; Regime; Landscape; } \\
\text { Experimenting; Envisioning }\end{array}$ & $\begin{array}{l}\text { Sust. product service systems, } \\
\text { open and user-driven innovation; } \\
\text { user acceptance }\end{array}$ & $\begin{array}{l}\text { Recursive Learning; } \\
\text { Institutionalised Learning }\end{array}$ \\
\hline $\begin{array}{l}\text { c) Rationale for the } \\
\text { specific } \\
\text { (transdisciplinary) } \\
\text { approach }\end{array}$ & $\begin{array}{l}\text { Irritation of complex, non-trivial } \\
\text { and self-referential social } \\
\text { systems }\end{array}$ & $\begin{array}{l}\text { Social reality as historically } \\
\text { constructed and therefore } \\
\text { intertwined with power relations. } \\
\text { Goal is helping marginalised } \\
\text { groups }\end{array}$ & $\begin{array}{l}\text { Transdisciplinary for coping with } \\
\text { complex, socially relevant } \\
\text { problems and uncertainty }\end{array}$ & $\begin{array}{l}\text { Focus on "wicked problems", TD } \\
\text { is required, if system, } \\
\text { transformation and orientation } \\
\text { knowledge are lacking }\end{array}$ & $\begin{array}{l}\text { UTL as a new governance } \\
\text { structure for sust. cities }\end{array}$ & $\begin{array}{l}\text { Transforming society into one } \\
\text { that features sustainable patterns } \\
\text { of production and consumption }\end{array}$ & $\begin{array}{l}\text { Research as dissent about the } \\
\text { reliability of knowledge as well as } \\
\text { about non-action }\end{array}$ \\
\hline $\begin{array}{l}\text { d) Aim of the } \\
\text { process }\end{array}$ & $\begin{array}{l}\text { Self-Enlightenment (in groups) } \\
\text { through instructed self-reflection, } \\
\text { opening new courses of action }\end{array}$ & $\begin{array}{l}\text { Production of new theories, } \\
\text { social innovations, initiation of } \\
\text { social movement, empowerment } \\
\text { and capacity building }\end{array}$ & $\begin{array}{l}\text { Production of relevant, socially } \\
\text { robust knowledge that also feeds } \\
\text { back to scientific knowledge } \\
\text { generation and theory building }\end{array}$ & $\begin{array}{l}\text { TD processes have to produce } \\
\text { new knowledge and facilitate } \\
\text { mutual learning between } \\
\text { scientists and practitioners }\end{array}$ & $\begin{array}{l}\text { UTL "provides space and time for } \\
\text { learning, reflection and } \\
\text { development of alternative } \\
\text { solutions that are not self- } \\
\text { evident" (Nevens et al., 2013, p. } \\
\text { 115) }\end{array}$ & $\begin{array}{l}\text { Enabling innovation processes in } \\
\text { which users and actors actively } \\
\text { participate in development, } \\
\text { testing and marketing phases of } \\
\text { sust. products/ lifestyles }\end{array}$ & $\begin{array}{l}\text { Knowledge production from } \\
\text { former experiments for } \\
\text { application in new experiments; } \\
\text { institutionalised learning to deal } \\
\text { with uncertainty }\end{array}$ \\
\hline $\begin{array}{l}\text { e) Typical } \\
\text { process and } \\
\text { duration }\end{array}$ & $\begin{array}{l}\text { 1. Researchers build relations in } \\
\text { soc. system } \\
\text { 2. Data collection; hypotheses; } \\
\text { interpret. } \\
\text { 3. Present findings; feedback and } \\
\text { reaction session } \\
\text { 4. Practitioners' decisions } \\
\text { Duration: some mos to a few yrs }\end{array}$ & $\begin{array}{l}\text { No standardized process but } \\
\text { similar steps } \\
\text { 1. Identification of problems } \\
\text { 2. Research design, data } \\
\text { collection and analysis } \\
\text { 3. Take action, implementation } \\
\text { 4. Evaluation } \\
\text { Duration: some mos to a few yrs }\end{array}$ & $\begin{array}{l}\text { 1. Joint probl. definition } \\
\text { 2. Joint probl. representation } \\
\text { 3. Jointly inititating a process of } \\
\text { problem-solving } \\
\text { Achieved by a set of methods } \\
\text { Duration: normally } 1-2 \text { yrs }\end{array}$ & $\begin{array}{l}\text { 1. Common research object } \\
\text { (problem transformation) } \\
\text { 2. Production of new knowledge } \\
\text { (interdisciplinary integration) } \\
\text { 3. Transdisciplinary integration } \\
\text { (evaluation of new knowledge) } \\
\text { Duration: a few yrs }\end{array}$ & $\begin{array}{l}\text { 1. Analysing the system } \\
\text { 2. Envisioning } \\
\text { 3. Exploring pathways } \\
\text { 4. Experimenting } \\
\text { 5. Assessing } \\
\text { 6. Translating } \\
\text { Duration: a few yrs }\end{array}$ & $\begin{array}{l}\text { 1. Insight research (household- } \\
\text { analysis of material flows and } \\
\text { patters of actions) } \\
\text { 2. Prototyping (scenarios and } \\
\text { prototypes) } \\
\text { 3. Field testing (extended scope) } \\
\text { Duration: some mos to a few yrs }\end{array}$ & $\begin{array}{l}\text { Recursive Learning: } \\
\text { 1. System } \\
\text { 2. Observing } \\
\text { 3. Recognizing } \\
\text { 4. Planning } \\
\text { 5. Action/Application } \\
\text { Duration: reflection on past yrs or } \\
\text { decades }\end{array}$ \\
\hline $\begin{array}{l}\text { f) Roles of scientists } \\
\text { and } \\
\text { practitioners, } \\
\text { leadership }\end{array}$ & $\begin{array}{l}\text { Sci: Data collection, interpretation } \\
\text { and presentatition; facilitation of } \\
\text { practitioner's deliberation } \\
\text { Prac: provide problems; } \\
\text { (instructed) self-reflection and } \\
\text { decision-making }\end{array}$ & $\begin{array}{l}\text { Sci: Participating in the social } \\
\text { context of the problem; data } \\
\text { collection } \\
\text { Prac: Involved throughout the } \\
\text { whole research process as equal } \\
\text { collaborators, become } \\
\text { empowered }\end{array}$ & $\begin{array}{l}\text { Sci: Facilitating TD } \\
\text { collaborations; shaping the } \\
\text { process; system analysis; } \\
\text { knowledge integration } \\
\text { Prac: Public at large and } \\
\text { legitimised decision maker; partly } \\
\text { in control } \\
\text { Ideal: co-leadership (equal } \\
\text { footing) }\end{array}$ & $\begin{array}{l}\text { Sci: Production and evaluation of } \\
\text { new knowledge; science } \\
\text { facilitates the process, is critical } \\
\text { and self-reflexive } \\
\text { Prac: provides specific } \\
\text { knowledge } \\
\text { Ideal: collaborative (research) } \\
\text { team }\end{array}$ & $\begin{array}{l}\text { Sci: coordination, pooling and } \\
\text { influencing actors and their } \\
\text { activities } \\
\text { Prac: innovative 'regime' actors } \\
\text { and frontrunners from 'niche' } \\
\text { contexts } \\
\text { Ideal: strong mutual trust }\end{array}$ & $\begin{array}{l}\text { Sci: system analysis; } \\
\text { constructing prototypes; enabling } \\
\text { users to innovate products and } \\
\text { behaviour; evaluation and } \\
\text { dissemination } \\
\text { Prac: providing data; ideating and } \\
\text { testing prototypes }\end{array}$ & $\begin{array}{l}\text { Sci: (Retrospectively) research } \\
\text { on processes of societal change } \\
\text { Prac: Real world experiment exist } \\
\text { independent of research }\end{array}$ \\
\hline $\begin{array}{l}\text { g) Generalisation of } \\
\text { results }\end{array}$ & $\begin{array}{l}\text { No reproducibility intended; only } \\
\text { local, situated and limited } \\
\text { knowledge }\end{array}$ & $\begin{array}{l}\text { Theories of social practice for } \\
\text { use beyond the immediate } \\
\text { research context }\end{array}$ & $\begin{array}{l}\text { Focus on knowledge integration } \\
\text { for the specific case }\end{array}$ & $\begin{array}{l}\text { Differentiation between useful } \\
\text { results for scientific and societal } \\
\text { practice; critical about } \\
\text { transferability of case study } \\
\text { results }\end{array}$ & $\begin{array}{l}\text { The UTL aim is a new } \\
\text { governance for sustainable cities; } \\
\text { no production of general } \\
\text { knowledge; "translation" of } \\
\text { knowledge to other fields }\end{array}$ & $\begin{array}{l}\text { Co-created new products, } \\
\text { services and newly configured } \\
\text { social practices are intended to } \\
\text { be diffused }\end{array}$ & $\begin{array}{l}\text { Reproducibility of generated } \\
\text { knowledge is intended, although } \\
\text { new uncertainties and learning } \\
\text { outcomes might arise }\end{array}$ \\
\hline
\end{tabular}


In the following, we highlight a variety of learning points for creating a comprehensive understanding of RWLs. We hereby focus on analytical criteria that allow to capture the basic logic of the different approaches and how it is put into practice. These aspects are most relevant for deriving key components of RWL research as the aim of this article. Criteria include the following: the rationale and aim of the specific approach $(c, d)$, its typical process and duration (e), considered roles of scientists and practitioners ( $f$ ), and position towards the generalisation of results ( $g$ ).

\section{Ad c, d) Rationale for the specific approach and aim of the process}

While almost all of the approaches justify their participatory research with systems complexity and a consequential lack of reliable knowledge, they tackle these challenges in quite different ways: Transdisciplinary approaches (Approach No. 3 and 4 in Table 1) generally address complex, socially relevant problems - mainly characterised as "wicked problems". They aim to produce new, "socially robust knowledge" (Nowotny et al., 2001) that will facilitate mutual learning among participants (Jahn, Bergmann, \& Keil, 2012, p. 3ff; Scholz, 2011, p. 373f; Vilsmaier et al., 2015). Quite differently, participatory action research (No. 2) emphasises the role of socially constructed power relations when seeking for participatory knowledge production. Thus, the approach aims to initiate social movements, to empower marginalised groups and to foster capacity building (Kemmis \& McTaggart, 2000; Ozanne \& Saatcioglu, 2008, p. 423ff). Intervention research (No 1.) is based on the assumption of complex, non-trivial and self-referential social systems. Therefore it seeks to impinge on and irritate a system in order to offer new courses of action and initiate "selfenlightening" learning through structured self-reflection (Hübner, 2012, p. 169).

Urban transition labs (No. 5) are contrasting with participatory action research as they do not focus on groups marginalised by socially constructed power asymmetries. The approach rather focuses on empowering innovative practices, ideas or social relations proposed by niche-actors. They are marginalised due to their misfit with socio-technical configurations of the dominant regime and/or landscape (Geels, 2002; Geels \& Schot, 2007). Urban transition labs are thereby defined as a new governance structure that "provides space and time for learning, reflection and development of alternative solutions that are not self-evident" (Nevens, Frantzeskaki, Gorissen, \& Loorbach, 2013, p. 115). Thus, solutions should go beyond purely incremental technical improvements.

We see RWLs being based on the assumptions of TD research and the ideals of urban transition labs. RWLs foster and enable sustainability transitions on the ground. Transformation knowledge is created which is not only helpful for practitioners but, on a more abstract level, to evaluate and create scientific theories as well.

\section{Ad e) Typical process and duration}

While the analysed approaches show many particularities, two types of basic process conception can be differentiated with regard to how intervention and learning are organized. A cyclical concept of intervention and learning can be found in participatory action research (No. 2), transition 
management (No. 5) and certain transdisciplinary approaches (No. 3 and 4) (Carew \& Wickson, 2010; Kemmis \& McTaggart, 2000, p. 596; Kemp \& Loorbach, 2006; Ozanne \& Saatcioglu, 2008). Most other approaches employ a rather linear model of knowledge production and integration.

In our perception, the cyclical combination of intervention and learning appears particularly suitable for RWLs. Real-world complexity is better tackled with a reflexive and flexible approach.

A second core aspect characterising the processes in the different approaches is the duration of a typical process. Large differences exist between the analysed approaches, probably influenced by funding schemes and process aims. Consulting projects rather vary in time and might run for only a couple of months. Transdisciplinary case studies which often involve educational components/students, generally have a clear time frame of 1-2 years. Publicly funded research projects normally run 2-4 years. Urban transition labs in correspondence to the long-term scope of transition are framed more long term. The duration of a typical RWL will be highly dependent from public funding as well and therefore be about 2-4 years as well. However, it has been postulated that RWLs should run for a much longer period, being able to accompany, foster and evaluate change over some decades (WBGU, 2016, p. 31).

\section{Ad f) Roles of scientists and practitioners}

All participatory approaches (No. 1-6 in Table 1, not comprising No. 7) are characterised by research activities that go beyond a passive collection of data. However, their understanding of the researcher's role varies considerably. It ranges from that of a coordinator and facilitator in the knowledge integration process (Jahn et al., 2012, p. 9; Scholz, 2011, p. 374f.) to an instructor in group self-reflection (Hübner, 2012, p. 169; Krainer \& Lerchster, 2012a, p. 10) and empowerment (Kemmis \& McTaggart, 2000; Ozanne \& Saatcioglu, 2008, p. 242ff.). Furthermore it includes the role of partner and enabler for innovative products and services (Geibler et al., 2013; Liedtke, Baedeker, Hasselkuß, Rohn, \& Grinewitschus, 2015) and the role of a critical and self-reflexive evaluator (Jahn et al., 2012, p. 9). Practitioners' roles in participatory research are defined according to the specific aims and structures of the real-world problem itself. This also determines with whom researchers collaborate and which form participation takes. In participatory action research (No. 2) for instance, practitioners are considered as equal collaborators (Ozanne \& Saatcioglu, 2008, p. 242f.). Scholz (2011, p. 388) differentiates between "legitimized decision-makers" and the "public at large". Both groups participate in selected process steps (Scholz, 2011, p. 388). Sustainable Living Labs construe their participants not only as active partners in innovation processes but also as passive test subjects and data suppliers. The latter approach would almost certainly be criticised by action researchers and also by some TD approaches. Scholz and Steiner (2015c) as well as Binder et al. (2015) ask for a "truly-lived co-leadership" that is based on "equal footing, authentic collaboration, and securing benefits for both science and practice" (Scholz \& Steiner, 2015c, p. 523). This understanding, combined with well-reflected varying roles of scientists and practitioners at different stages, is instructive for the RWL approach. 


\section{Ad g) Generalisation of results}

Concerning the question of generalisation of results, several positions can be identified. Intervention research does not intend reproducibility, as knowledge is considered local and situated (Krainer \& Lerchster, 2012a, p. 13). Participatory action research (No. 2) in contrast aims to test and build up theories of social practice for scientific use beyond the immediate research context (Ozanne \& Saatcioglu, 2008, p. 246). Transdisciplinary approaches (No. 3 and 4) see great potential for the transferability of results if they can be integrated in the existing body of scientific knowledge, which in turn poses a major challenge (Lang et al., 2012). Here, we can also find the strongest call of all approaches for results that should also feed back into the scientific knowledge generation and theory building. In urban transition labs, the dissemination of the yielded results for governance innovations is rather seen as a process of "translating" the practical lessons learnt (Nevens et al., 2013, p. 115).

We find the assumptions of intervention research and urban transition labs most helpful for understanding the essence of a RWL, which then is a contextualised testbed for sustainability transitions. We therefore share the critical viewpoint on a broad generalisability of results to the scientific body of knowledge. Connecting to the TD approaches, RWLS should ideally generate experience and learning with a benefit for scientific theory-building and testing. However, the main focus lies on fostering real-world change (see also ch. 4.4).

Summing up our literature review, we learned that knowledge and experience from TD research, action research and other streams like transition management or sustainable living labs help to sharpen and contrast the idea of a RWL. On that basis, our RWL key components are ready to be devised.

\section{Key components for Real-World Laboratories}

Building on the definitions and understandings of RWLs in chapter 1 and our review of conceptually and empirically well-established related approaches in chapter 2, we propose a list of eight key components that we consider crucial for the installation and implementation of a RWL.

\section{Table 2: Eight key components of a Real-World Laboratory}

Column 2 names the component, column 3 shows the origin of the component building on the reviewed literature on RWLs (chapter 1) and similar approaches (chapter 2). Column 4 lists further details and explanations of the component. Alphanumerical references refer to characteristics of related approaches (table fields or complete rows in Table 1).

\section{No Component}

1. Normative framing: aiming to contribute to sustainable development
Origin/Reference

RWL definitions and understandings

MWK, 2013, p. 30

Parodi et al., 2016

WBGU, 2016, p. 512

Similar approaches

see row $c$

\section{Description/ Comments}

RWLs aim to contribute to sustainable development, as many transdisciplinary and transformative approaches and urban transition labs more or less explicitly do (row c, esp. c3, c4 and c5). 
2. Production of systems-, target- and transformation knowledge (mostly contextualised)

3. Real-world problems as a starting point

4. Boundaries: "Laboratory" demarcations, defined by content and space understandings

WBGU, 2016, p. 512

Similar approaches see c4
RWL definitions and

RWLs contribute to the production of all three knowledge types. Due to an often local setting or a very specific problem, the produced knowledge is mostly contextualised (Karvonen \& van Heur, 2014, p. 385f).

Target knowledge may not only be produced through e.g. generating scenarios but also by the process of envisioning (see urban transition labs (Nevens et al., 2013, p. 114).

RWL definitions and understandings Schneidewind, 2014, p. 3

RWLs, as other participatory research approaches almost always take real-world problems as a starting point. Component 3 is informed by component 1.

Wagner \& Grunwald, 2015, p. 26

WBGU, 2016, p. 512

Similar approaches

see all approaches

RWL definitions and understandings

MWK, 2013, p. 30

WBGU, 2016, p. 512

Similar approaches

see $\mathrm{e} 3$ and 44

5. Transdisciplinary collaboration (coleadership) with clear roles for practice and science

RWL definitions and understandings Schneidewind Singer-Brodowski, 2015, p. 15 Wagner \& Grunwald, 2015, p. 26 WBGU, 2016, p. 512 Similar approaches see row $f$

Content is defined by the real-world problem; Space is sometimes solely implicitly defined by content, e.g. in district RWLs it is quite often determined by administrative borders.
6. Real-world intervention (often called "experimentation")
7. Cyclical learning processes through reflection and variation

8. Empowerment of change agents and capacity building
RWL definitions and understandings

Schneidewind, 2014, p. 3

WBGU, 2016, p. 512

Similar approaches see row d

RWL definitions and understandings

(Schäpke, Stelzer, Bergmann, SingerBrodowski, et al., 2017, p. 5)

Similar approaches see e1, e2 and d5

RWL definitions and understandings
Collaboration with, rather than consultation of practice, is of particular importance in RWLs. A joint \& leadership (co-leadership) with the main practice partner(s) that goes beyond having mutual trust is aimed for.

In facilitating sustainability transitions, researchers act in different roles (Pohl et al., 2010; Wittmayer \& Schäpke, 2014). Facing different knowledges, interests and activities of science and practice, clearly defined roles are crucial in RWL.

In contrast to transdisciplinary processes, RWLs aim not only for the production of new, socially robust knowledge, but also for the reflection and calibration of a real-world interventions (see component 7).

The real-world intervention or "experimentation" is the core mode of knowledge production in RWLs (Schäpke et al., 2017, p. 5).

The importance of cyclical learning is extracted not only from action research and intervention research approaches (e1 and e2) but from certain living labs (Voytenko, McCormick, Evans, \& Schliwa, 2015) and urban transition labs (Nevens, Frantzeskaki, Gorissen, \& Loorbach, 2013, p. 115) as well. It has not been conceptualised properly for RWLs yet, although it is present in similar approaches.

As RWLs are transformative in nature and aim for sustainability transformations, they often rely on change agents as practitioners who wish to carry 
Similar approaches

see $\mathrm{d} 8$ and $\mathrm{f} 8$ out a real-world intervention or who take already action.

Approaches of transition management and action research aim to empower change agents resp. support frontrunners in niches.

\section{Flowchart of a practical Real-World Laboratory process}

Like every other planned and intentional endeavour, transdisciplinary and cooperative research activities profit from a clear and structured procedure. Nevertheless, no concrete guidelines for a RWL project have yet been published. To fill this gap and to guide practical application of RWLs, we develop a comprehensive flowchart for RWLs. Wiek and Lang (2016) for example have structured and compared four methodological frameworks for transformational sustainability research and synthesize an own framework integrating foresight, backcasting and intervention research. Similarly, we synthesise our own flowchart for the project "Well-being Transformation Wuppertal" on the basis of our key components (see chapter 3 ) and the comparison of transformation-oriented approaches (see chapter 2). Our concept basically builds on the comprehensive understanding of TD processes (Jahn et al., 2012; Lang et al., 2012). It combines this understanding with interventionist and experimental elements of action research, living lab and transition lab approaches without necessarily focussing on visioning, backcasting or scenario construction.

The explanation of the flowchart below (see figure 1 ) is divided in firstly explaining the constituting principles of our flowchart and secondly the in-built phases of co-design, co-production and coevaluation.

By transferring fuzzy understandings and definitions into key components and a flowchart of interrelated principles and process steps, RWLs become a specified and autonomous research practice. Thus, they move beyond being mere spatial figures of thought and inspiration for a broad range of cooperative science-practice interventions only. Furthermore, the proposed conception deliberates RWLs from - in our perception - overly narrow understandings of RWLs as being subcomponents of classical TD process only (compare Jahn and Keil (2016). In sum, this represents an important step forward in the meaningfulness of RWL research. 


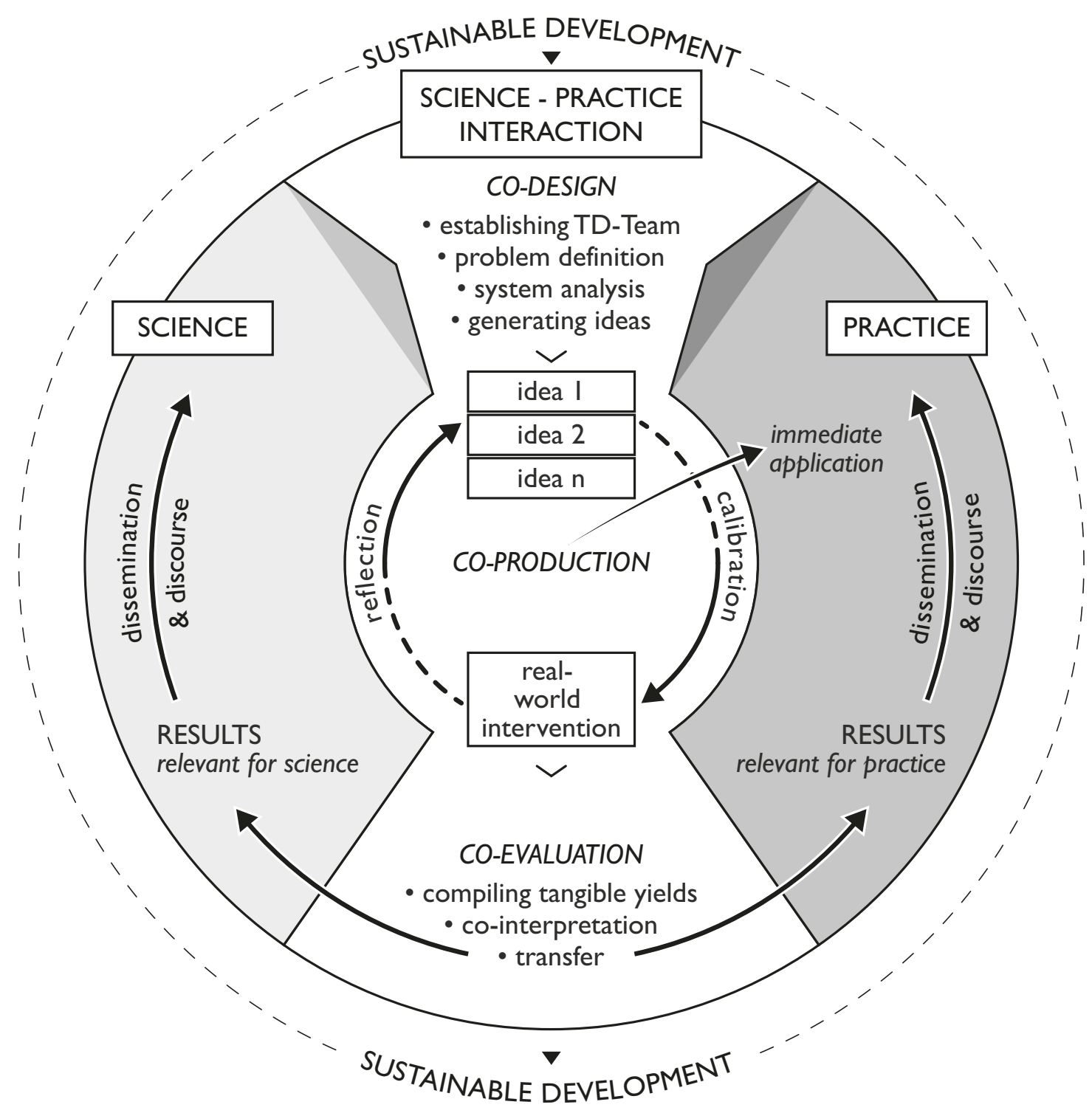

Fig. 1 Cyclical concept for Wuppertal's Real-World Laboratories.

Building on an overall normative orientation towards sustainable development, RWLs are depicted as being composed of science-practice interactions. The transdisciplinary research process in RWLS comprises three phases, co-creation, co-production and co-evaluation, including the development of ideas and real-world intervention(s). Two learning cycles characterise this process: first, coproduction includes reflection and calibration of ideas and interventions; second, overall results are reintegrated into science and practice and may refine the original problem definition and system understandings; Source: own graphic.

\subsection{Constituting principles and overall aim}

Our flowchart builds on the TD distinction between a scientific field "academia", "research context", "scientific problems") on the left and a field of practice ("stakeholder", "society", "real-world problems") on the right (Bergmann et al., 2005; Bergmann, 2010; Carew \& Wickson, 2010; Jahn et al., 2012; Lang et al., 2012; Miah et al., 2015). Project leaders from both spheres come together in a science-practice interaction and establish a solid partnership, ideally in a culture of co-leadership 
(Binder et al., 2015; Scholz, Lang, Wiek, Walter, \& Stauffacher, 2006; Scholz \& Steiner, 2015c). This reflects key component 5: transdisciplinary collaboration (co-leadership) with clear roles for practice and science. The actors embark on a project in order to tackle a socially relevant problem or field (Lang et al., 2012; Mogalle, 2001; Pohl \& Hirsch Hadorn, 2008), referring to key component 3: realworld problem as a starting point. A helpful and needed containment for the "laboratory" is the definition of boundaries, defined by content and space (key component 4). The actors form a team and proceed through the three phases of co-design, co-production and co-evaluation (Bergmann et al., 2005; Carew \& Wickson, 2010; Lang et al., 2012; Mauser et al., 2013), producing systems, target and transformation knowledge (key component 2). Scientific and practical knowledge is merged and integrated during the process. Thus, mutual learning with concrete, solution-oriented output is enhanced through real-world interventions or "experiments", fulfilling key component 6: real-world intervention/"experimentation"). The intervention(s) are reflected on and calibrated, if needed. This reflects key component 7: cyclical learning processes through reflection and variation. During the process, both sides stick to their roles (which might sometimes overlap) and transfer different results and findings back into their respective "system". RWL researchers take on different roles (see also key component 5 as mentioned). In Section 2 we already found explicit role descriptions in various approaches. According to Wittmayer \& Schäpke (2014), researchers can act in various different roles in transdisciplinary research. This includes the role of process facilitators (Hadorn, Pohl, \& Bammer, 2010; Scholz, 2011); as traditional scientists, systematically collecting, analysing, interpreting and reporting data and as knowledge brokers, mediating between different perspectives and providing space for critical reflection. Further roles are the change agent, explicitly participating in processes that address real-world problems (see section on co-production); and, finally, self-reflexive researchers. In this role, scientists think about their own position and its inherent normativity, seeing themselves as part of the system they address. Practice partners in RWLs mostly belong to the group of so called change agents who are likely to contribute to a sustainable development and are (aimed to be) empowered by the RWL process (key component 8 ).

Indicated by the outer dotted circle, we - just like other approaches do (Liedtke et al., 2015; Nevens et al., 2013) - see RWL research as a means to contribute to sustainable development in modern societies which is expressed by key component 1: normative framing: aiming to contribute to sustainable knowledge. Discussing the framework of sustainable development and its implications for each project with the TD team can be understood as a first intervention of the RWL (indicated by the small arrow in Figure 1).

\subsection{Co-design}

The phase of co-design sets the basic rules and framework for a project. A TD team must first be formed, and roles and interests identified and clarified. Care should be taken that researchers and practitioners meet on an equal footing, establishing a culture of co-leadership (Binder et al., 2015; Scholz, Lang, Wiek, Walter, \& Stauffacher, 2006; Scholz \& Steiner, 2015c). The TD team jointly coordinates tasks and repsonsibilities thoughout the project. TD projects and literature supply a large body of knowledge for these steps which refer to key component 5: transdisciplinary collaboration (Lang et al., 2012; Scholz \& Steiner, 2015b, 2015a). To date, RWLs have only primarily been established with public research funds, so initial meetings between scientists and practitioners generally take place during the application phase. Muhar et al. (2006) helpfully point out that 
achieving cooperation on an equal footing is additionally critical in projects that have been initiated in a top-down manner, for example by a university that primarily pursues academic output. Quite often, as suggested by the very idea of transformative research, practitioners are "change agents" (Kristof 2010, 529; WBGU 2011, 242ff) or, as expressed in the urban transition lab approach, "frontrunners from 'niche' contexts" (Nevens et al., 2013, p. 115).

Even if initially only a fuzzy understanding exists, care must be taken that all project partners have the same (or at least a similar) conception and definition of the problem (Hirsch Hadorn, Bradley, Pohl, Rist, \& Wiesmann, 2006, p. 124ff.). This should originate from a real-world issue (key component 3). Based on this, an overarching question has to be agreed upon, to guide the project. Nevertheless, due to the very different rationales of science and practice, the collaborating parties will additionally formulate their own goals - e.g. answering a clear-cut research question or finding a solution for a specific real-world problem. Part of the step of problem definition is the specification of boundaries, which might be spatial or content-related (key component 4). This is an ongoing process that might already start (implicitly) during the application phase or with the establishment of a TD team. Subsequently it will entail adaptation, especially with regard to actors and actor-groups engaged in certain spatial settings. Wagner and Grunwald exemplarily name settlement zones, regions, branches, institutions, or pioneers of change as potential boundaries (2015, p. 27), Caniglia et al. (2017) more abstractly differentiate between geographical-physical, interactive and communicative and resource-related dimensions of space for a RWL.

After achieving a joint understanding of the problem layout and its boundaries, a mutual understanding of the underlying system should be generated (system analysis; key component 2: systems knowledge). In the analysed research approaches, this step is taken in various different ways (see Table 1). The methods used range from qualitative phenomenological approaches to understanding a social field (Krainer \& Lerchster, 2012b), through actor and network analyses (Wittmayer, Roorda, \& Steenbergen, 2014), to a highly systematic quantitative model of stocks, flows, hierarchies, information flows etc. (Scholz \& Tietje, 2002). Choosing a specific method for depicting and analysing a system has implications for the intervention phase and the final evaluation. A rigorously systematic overview will probably lead to different intervention ideas than an open, parallel collection of various facets of the problem. A thoroughly generated systems model is particularly interesting, as it discloses points or nodes for intervention. With the help of a "conceptual model" (Scholz \& Tietje, 2002, p. 31), the TD team can set up the space for generating ideas that address the problem and lead to a defined target (key component 2: target knowledge). Projects following the transition management model mostly use visioning processes at this stage (Nevens et al., 2013; Wittmayer et al., 2014) in order to formulate a shared vision of a desirable future. The idea behind creating a shared vision lies in the assumption that "distant visions guide the journey" (Raskin et al., 2002, p. 43) and establish a "pull-factor" towards a desired future and not just away from a problem. Although visioning can be a powerful tool, not every project can and must engage in a comprehensive, time-consuming visioning process. Especially in a science-practice collaboration with change agents, a vision or target may have already been generated, or one can connect to other ongoing projects. Moreover, from our own experiences we can tell that it is sometimes harder and less effective to motivate a group of people to envision a better future than to invite them to support concrete ideas. 
Intervention ideas should ideally be linked to "leverage points" (e.g. Abson et al., 2017) or nodes identified during the system analysis, and should at best follow a theory of change - either in the form of practical guidelines and strategies for shaping the change process or as abstract conceptualisations of change patterns. This will be developed in the discussion at the end of this article.

Usual roles of practitioners at that stage are to provide a "real-world problem" and to contribute implicit and contextual knowledge. Researchers mostly act as reflective scientists or knowledge brokers and normally methodologically guide the development of a systems model. Some tasks in RWLs might be carried out by both researchers and practitioners. This includes for example the facilitation of the co-design phase, comprising the organisation and moderation of discussions. Additionally it includes the coordination of inputs from experts and multipliers, and other information and coordination tasks. Furthermore, it might be interesting to think about involving a third party or institution to act as a hinge and take care of tasks like project management and facilitation for the whole RWL inquiry.

\subsection{Co-production}

This phase of co-production takes the RWL to real-life action in the chosen intervention field. In this, RWLs explicitly go beyond the generation of theoretical knowledge. They enter a cyclical process of learning through "experimentation", reflection and calibration (key components 6 and 7: real-world intervention and cyclical learning processes through reflection and variation). This "trial-and-error" approach is based on evolution and innovation theory. This theory explains how new (sustainable) practices emerge, disseminate and replace old, unsustainable behaviours and structures (Geels, 2002; Kemp, Schot, \& Hoogma, 1998). RWLs are in this respect informed by the idea of niche-level activity and real-world experimentation (Kemp et al., 1998; van den Bosch, 2010, p. 47ff). Thereby researchers need to bear in mind, that collective real-world processes, social innovation and sustainable practices can be controlled only to a certain extent (Rückert-John, 2013, p. 304).

In the actual practice of co-production (see centre of Figure 1), the TD team will engage in real-world action, reflecting on and learning from the ongoing process. Roles in this process are basically split. The practitioners drive the process, test and calibrate the ideas, and the researchers stand close by, reflecting on the action (see key component 5: clear roles for practice and science). Researchers profit from being "disengaged from praxis" but cultivate close feedback loops and constant communication with practitioners. Nevertheless, we hold that researchers' background will at least to a certain extent define the process of intervention and calibration. This is due to their own normativity (fostering sustainable development), their presence and inputs during the co-design phase, and their somehow biased reflections. Researchers therefore need training, as well as a supportive team, in order to work fruitfully with these challenges, as respective qualifications are not traditionally part of the repertoire of scientists.

Ongoing reflection on processes, and on the results of implementing ideas, are constitutive for the cyclical co-production process. Techniques of formative evaluation - carried out mostly by researchers - are helpful to support the ongoing learning process. They allow for timely adjustments before the final project evaluation (Bergmann et al., 2005). Action research approaches have also 
developed helpful guidelines for jointly collecting and using data in cycles of action and reflection (von Unger, 2014, p. 59f).

Real-world interventions in the field may lead to direct results for practice (see arrow from coproduction to practice). This may take the form of new platforms, narratives, prototypes, policies, services, (social) business models, individual or collective mind-shifts, new capabilities, resources or legal action and others (key component 8: empowerment of change agents and capacity building). These outcomes from the co-production process may well be limited in their reproducibility and usefulness in other areas or settings due to their high context dependency. Their potential for generalisation has to be analysed at the end of the project.

\subsection{Co-evaluation}

Reflecting on and evaluating activities undertaken in a RWL starts at the beginning, not at the end of a project (see point reflection above, key component 7: cyclical learning processes). Nevertheless, a final evaluation sheds more light on the overall knowledge, interactions, interventions, outputs and outcomes produced. Thereby "'failure' of experiments should be considered/allowed as part of the game" (Nevens et al., 2013, p. 119) and as an opportunity for learning.

But how to understand the effects of a RWL and how to evaluate them? There are different options. Linear logic models distinguish between different stages of a project and propose sequences of action. One widely used model differentiates five sequential components. It starts with inputs (1) and processes/activities (2), and moves from there to proximal effects of outputs (3) and outcomes (4), before going on to remoter societal impacts (5) (Bornmann, 2013; Penfield, Baker, Scoble, \& Wykes, 2014; Wiek, Talwar, O'Shea, \& Robinson, 2014). Inputs here relate to the resources used for the project. Processes are all activities undertaken during the project. Outputs relate to the direct effects of those activities. Outcomes are the short and medium term results or changes that can at least partly be linked to the (sub-)project. Societal impacts finally are long-term effects. In this line of thought, outcome evaluation is based on the compilation of tangible yields, such as the documented activities and outputs.

Societal impacts are more difficult to be attributed to the project and its activities. Bearing the flowchart in mind, they would be located on the framework level of sustainable development. Penfield et al. (2014) list several problems concerning impact evaluation like time-lag, the developmental nature of impact, attribution, knowledge-creep and the lack of gathered data. Therefore, in contrast to linear logics of outcome and impact assessment at the end of a (hypothesised) attribution chain, there are ideas of assessing contributions of research projects differently. Spaapen and Van Drooge (2011) propose to concentrate on "productive interactions" between researchers, stakeholders and the environment in order to better understand the processes that induce societal impact (and not just their outcomes). RWL evaluation schemes should further discuss approaches like these.

Ideally, every RWL project should engage in measuring its societal impact, using comprehensive assessment schemes (Erawatch Network ASBL, 2013; Luederitz et al., 2016; OECD, 2010; Wiek et al., 2014). Still, this requires considerable resources of time, competence and money which may pose limits to the comprehensiveness of the evaluation. Additionally, it may take time until interventions 
show effect. An option could therefore be to measure impacts on a level of second-order learning in consecutive projects or performing meta-analyses after a couple of projects are completed.

The researcher's role is to provide an overall evaluation concept, prepare evaluation meetings and connect formative and final evaluations. The actual co-interpretation and evaluation of outcomes should be conducted jointly by the team of researchers and practitioners, using available guidelines for cooperative reflection (Roux, Stirzaker, Breen, Lefroy, \& Cresswell, 2010; von Unger, 2014, p. $61 \mathrm{ff})$.

After a joint co-interpretation and co-evaluation of outcomes, the results have to be transferred back into the systems of both science and practice. Transfer into practice means condensing the lessons learnt. Therefore, patterns of success or failure are extracted on an abstract level, building on the strongly contextualised actions produced during the co-production phase. Possible products might for example be guidelines, handbooks, dos and don'ts and new governance practices. For transferring insights back into the scientific system, generated outputs and outcomes are interpreted in the light of the initial research question and the conceptual model. Results furthermore are embedded into the theoretical and methodological state of the art of the related scientific communities. Possible products will take the form of scientific papers, articles or books.

For both practice and science, results can ideally be generalised. This means firstly embedding them in a bigger picture and secondly drawing conclusions (e. g. on effective contributions to sustainable development) that are valid in different places and settings as well (Przyborski \& Wohlrab-Sahr, 2014 , p. 362). For transfer and dissemination, the setting is of major importance. The possibility to achieve transformational knowledge of general validity can nevertheless be up for debate: Transdisciplinary processes such as RWLs deal with socially relevant problems marked by uncertainty and complexity (Jahn et al., 2012, p. 8; Pohl \& Hirsch Hadorn, 2008, p. 34; Scholz, 2011, p. 374). Furthermore, RWLs take place in a specific, unrepeatable spatial and temporal setting. Not only from a cultural and sociological, but also from a political standpoint it is clear that the capacity for action and problem solving is deeply intertwined with the inherent logic, narratives and "Eigenart" of cities or districts (Löw, 2012; WBGU, 2016). Against this background of partly or even wholly uncontrolled conditions and real-world interventions, it is even more important to focus on results on the level of system models, prototypes and/or patterns (Schneidewind \& Scheck, 2013). This may involve weakening classical quality criteria like reliability and external validity for the sake of increased ecological validity (the setting of the study approximates the real-world).

\section{Illustration of how the developed RWL concept is used in Wuppertal's Mirke district}

The project "Well-being Transformation Wuppertal" (WTW) is located at TransZent, the Center for Transformation Research and Sustainability, founded jointly by the University of Wuppertal and the Wuppertal Institute. The project aims to establish a broad and practicable indicator system of urban well-being (OECD, 2015). Therefore a joint vision of a good life in the overall city of Wuppertal is developed in collaboration with Wuppertal's urban community. Main participating groups included the organised civil society, the city administration, and change agents. Additionally, three RWLs are installed on a district level in order to learn about local production of sustainable well-being (Rose et al. in this volume). 
One of the partnering districts is Mirke located north of Wuppertal's city centre. Some 8.100 people live in this district that struggles with issues such as unemployment, child poverty and a high level of vacant accommodation (Stadt Wuppertal, 2014). Socio-cultural institutions are core actors in the district. They reach out to marginalised groups, provide a high-class international cultural programme and reinvent bottom-up district development. Thereby, they focus on inclusion, the common good and sufficiency practices. One main actor is the creative cluster and social entrepreneur Utopiastadt ("Utopia City"). As a practice partner of WTW, Utopiastadt integrates accessible cultural events and impactful inspirations for district and city development (Palzkill, Wanner, \& Markscheffel, 2015). This includes gastronomy, urban gardening, open data initiatives, post-fossil mobility and co-working spaces. Utopiastadt is located in a former railway station dating from 1882, whose tracks now form part of a cross-city bike lane.

The science-practice team consists essentially of a research fellow from TransZent ("researcher"), a managing director of Utopiastadt and a chairperson of the Utopiastadt Friends and Benefactors Association ("practice partners").

Activities realised by the project up to date are explained step by step in Table 3.

\section{Table 3: The RWL research process in the Mirke district of Wuppertal}

Process steps from the developed flowchart and the associated key components (see chapter 3) are depicted in the left column. Main activities undertaken in RWL Mirke related to different components and steps are shown in the middle-left column. The middle-right column lists stakeholders involved in the different activities and rates their relevance (1: no relevance/ 5: high relevance) (Binder et al., 2015, p. 554). A critical reflection on the quality of the process is included in the right column (Rating: $( \pm)$ overall neutral, $(-)$ negative, $(+)$ positive, according to coherence of process in Mirke with steps proposed in conceptual flowchart).

Flowchart step Activities
and key
component(s)

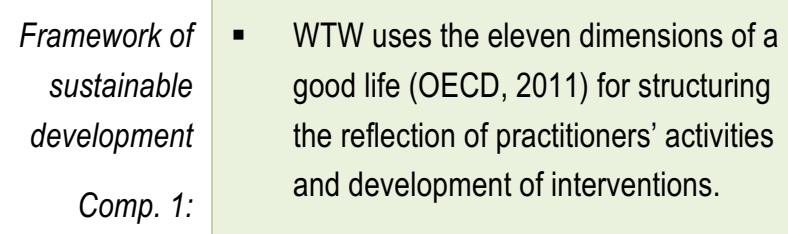

normative framing
Involved

stakeholders

(relevance 1 to 5)

Acquisition leader from the Wuppertal Institute (5), researcher (1) and practice partner (1)

\section{Reflection and lessons}

( \pm ) The framework was onesidedly introduced by the Wuppertal Institute and can therefore be seen as a first intervention.

(+) However, it sparked interesting reflections on activities at Utopiastadt and proved useful for better understanding activities contributing to well-being.

\section{Co-Design}

Establishing TD team
- Cooperation between Utopiastadt and TransZent began in 2014 , leading to trustful agreements during the
Researcher (5) and practice partners (5)
(+) Established communication channels enormously facilitate 


\begin{tabular}{|c|c|c|c|}
\hline $\begin{array}{r}\text { Comp. } 5: \text { td } \\
\text { collaboration with } \\
\text { clear roles }\end{array}$ & $\begin{array}{l}\text { application phase for WTW. } \\
\text { Roles of science and practice were } \\
\text { defined orally. }\end{array}$ & & $\begin{array}{l}\text { cooperation during the } \\
\text { application phase. } \\
\text { (-) Due to restrictive funding } \\
\text { rules, no budget was } \\
\text { assigned to the practice } \\
\text { partner. } \\
( \pm) \text { No written cooperation } \\
\text { and task allocation, only oral } \\
\text { understanding. }\end{array}$ \\
\hline $\begin{array}{r}\text { Problem definition } \\
\text { and } \\
\text { representation; } \\
\text { defining } \\
\text { boundaries } \\
\text { Comp. 3, 4: real- } \\
\text { world problem as } \\
\text { a starting point \& } \\
\text { boundaries }\end{array}$ & $\begin{array}{l}\text { - An overview of multiple running projects } \\
\text { or project ideas at Utopiastadt and in the } \\
\text { district led to a quick joint rating of } \\
\text { urgency, scientific and practical } \\
\text { compatibility and matching with the } \\
\text { OECD dimensions of ideas. Underlying } \\
\text { problems were implicitly assumed or } \\
\text { taken as already clear. } \\
\text { The rough rating procedure suggested a } \\
\text { very concrete thematic project: analysing } \\
\text { and supporting an already newly } \\
\text { founded exchange platform for district } \\
\text { development, called Forum:Mirke (F:M). } \\
\text { Spatial boundaries of the recently } \\
\text { defined district were agreed on. }\end{array}$ & $\begin{array}{l}\text { Researcher ( } 3 \text { ) and } \\
\text { practice partners ( } 5)\end{array}$ & $\begin{array}{l}(+) \text { A joint reflection on } \\
\text { Utopiastadt activities led to a } \\
\text { structured overview of } \\
\text { possible intervention points, } \\
\text { covering different OECD } \\
\text { well-being dimensions. } \\
(-) \text { No underlying problem } \\
\text { definition was made, } \\
\text { assuming that all activities of } \\
\text { Utopiastadt already relate to } \\
\text { a defined problem. }\end{array}$ \\
\hline $\begin{array}{r}\text { System analysis } \\
\text { and integration of } \\
\text { knowledge } \\
\text { Comp. 2: } \\
\text { systems,- target- } \\
\text { and } \\
\text { transformation } \\
\text { knowledge }\end{array}$ & $\begin{array}{l}\text { - Due to the quick decision to focus on } \\
\mathrm{F}: \mathrm{M} \text {, the platform was understood as } \\
\text { "the system". Document analysis of the } \\
\text { minutes taken at the six previous F:M } \\
\text { meetings and ten interviews with } \\
\text { different, sometimes opposed actors in } \\
\text { the district were performed by the } \\
\text { researcher. A qualitative content } \\
\text { analysis was conducted. } \\
\text { A comprehensive system analysis of the } \\
\text { district was conducted only later, due to } \\
\text { deeper reflection processes (see below) }\end{array}$ & $\begin{array}{l}\text { Researcher (5), } \\
\text { practice partners (3), } \\
\text { public at large from } \\
\text { the district, active in } \\
\text { Forum:Mirke (2) }\end{array}$ & $\begin{array}{l}\text { (-) Simple and unsystematic } \\
\text { analysis of the system of } \\
\text { bottom-up district } \\
\text { development and } \\
\text { communication networks. } \\
\text { The generation of a system } \\
\text { model would have been } \\
\text { helpful. } \\
(+) \text { Shared interpretation of } \\
\text { the outcomes of the } \\
\text { interviews, leading to joint } \\
\text { understanding of the } \\
\text { problem. }\end{array}$ \\
\hline $\begin{array}{r}\text { Generating ideas } \\
\text { Comp. 5, 6: td } \\
\text { collaboration \& } \\
\text { real-world } \\
\text { intervention }\end{array}$ & $\begin{array}{l}\text { Based on the content analysis, } \\
\text { proposals for the development of the } \\
\text { F:M were derived jointly. Results were } \\
\text { presented at a public F:M meeting. Main } \\
\text { idea: installing a stable, regular } \\
\text { organizing team for the F:M. }\end{array}$ & $\begin{array}{l}\text { Researcher (5) and } \\
\text { practice partners (4), } \\
\text { public at large, active } \\
\text { in Forum:Mirke (2) }\end{array}$ & $\begin{array}{l}\text { (-) Proposals for intervention } \\
\text { had apparent initial validity } \\
\text { but no systematic anchoring. } \\
(+) \text { Transparent handling of } \\
\text { results and aims. }\end{array}$ \\
\hline \multicolumn{4}{|l|}{ Co-Production } \\
\hline $\begin{array}{l}\text { First idea and } \\
\text { real-world }\end{array}$ & $\begin{array}{l}\text { - Practice partners decided on the six } \\
\text { members of the new organising team. }\end{array}$ & $\begin{array}{l}\text { Practice partner }(5) \\
\text { and six active }\end{array}$ & $\begin{array}{l}(+) \text { Mostly clear division of } \\
\text { roles. }\end{array}$ \\
\hline
\end{tabular}




\begin{tabular}{|c|c|c|c|}
\hline $\begin{array}{l}\text { intervention } \\
\text { Comp. 6: real- } \\
\text { world intervention }\end{array}$ & $\begin{array}{l}\text { The researcher facilitated four } \\
\text { consecutive sessions of structured } \\
\text { organisation development. }\end{array}$ & $\begin{array}{l}\text { stakeholders from the } \\
\text { district (3), researcher } \\
\text { (5) }\end{array}$ & $\begin{array}{l}\text { (-) Excessive demand of } \\
\text { researcher facilitating, } \\
\text { documenting and reflecting } \\
\text { the sessions. A third-party } \\
\text { facilitator would have been } \\
\text { helpful. }\end{array}$ \\
\hline $\begin{array}{r}\text { Reflection and } \\
\text { calibration } \\
\text { Comp. 7: cyclical } \\
\text { learning } \\
\text { processes }\end{array}$ & $\begin{array}{l}\text { - The initial burning issue of benefitting } \\
\text { from a (small) promised municipal fund } \\
\text { became marginal, as the administration } \\
\text { decided to put the money into a district } \\
\text { fund. } \\
\text { - Dealing with concrete questions of } \\
\text { bottom-up district development led to } \\
\text { disciplinary reflection of relations } \\
\text { between civic engagement, place } \\
\text { identity and perceived self-efficacy. A } \\
\text { systematic, environmental psychological } \\
\text { survey was mooted and is planned by } \\
\text { the researcher. Results flow back into } \\
\text { the F:M. } \\
\text { In plus, the interest of both the } \\
\text { researcher and the practice partner in a } \\
\text { comprehensive systemic overview of the } \\
\text { district development grew bigger (due to } \\
\text { the occupation with the flowchart model). } \\
\text { Three workshops for conducting a } \\
\text { participatory constellation analysis } \\
\text { (Schön, Kruse, Meister, Nölting, \& } \\
\text { Ohlhorst, 2007) were carried out. The } \\
\text { outcomes will lead to a deeper reflection } \\
\text { of fruitful next interventions. }\end{array}$ & $\begin{array}{l}\text { City administration as } \\
\text { intervening power (5), } \\
\text { organising team } \\
\text { Forum:Mirke, } \\
\text { including practice } \\
\text { partners (4) and } \\
\text { researcher (1) } \\
\text { Researcher (5) } \\
\text { Researcher (5), } \\
\text { TransZent team (2), } \\
\text { nine active } \\
\text { stakeholders from the } \\
\text { district, inlcuding the } \\
\text { practice partners (4) }\end{array}$ & $\begin{array}{l}(+) \text { Researcher and } \\
\text { practitioners reacted to the } \\
\text { course of things, decreased } \\
\text { their involvement in F:M and } \\
\text { expanded activities to } \\
\text { different areas. } \\
(-) \text { The lack of initial } \\
\text { systematisation of the forces } \\
\text { driving the bottom-up district } \\
\text { development made it difficult } \\
\text { to assign activities to a } \\
\text { coherent strategy. }\end{array}$ \\
\hline $\begin{array}{r}\text { Second idea and } \\
\text { real-world } \\
\text { intervention } \\
\text { Comp. 6: real- } \\
\text { world intervention }\end{array}$ & $\begin{array}{l}\text { - The high level of interest of Utopiastadt } \\
\text { and TransZent in integrating scientific } \\
\text { knowledge and capacity for a reflexive } \\
\text { district development led to the idea of a } \\
\text { regular, open and jointly coordinated } \\
\text { round table for collaborative inter- and } \\
\text { transdisciplinary research. }\end{array}$ & $\begin{array}{l}\text { Practice partners (5) } \\
\text { and researcher (5), } \\
\text { variety of students } \\
\text { and graduates (3), } \\
\text { interested citizens (1) }\end{array}$ & \\
\hline $\begin{array}{r}\text { Reflection and } \\
\text { calibration } \\
\text { Comp. 7: cyclical } \\
\text { learning proc. }\end{array}$ & $\begin{array}{l}\text { - The co-researching group attracts } \\
\text { attention by academic staff. Whole } \\
\text { seminars and courses from different } \\
\text { faculties have begun to study the district. }\end{array}$ & $\begin{array}{l}\text { Practice partners (5) } \\
\text { and researcher (4), } \\
\text { teaching staff from } \\
\text { university (5), } \\
\text { students (2) }\end{array}$ & $\begin{array}{l}\text { (-) Whole seminars haven't } \\
\text { participated in the round } \\
\text { table yet and therefore don't } \\
\text { experience the inter- and } \\
\text { transdisciplinarity }\end{array}$ \\
\hline $\begin{array}{r}\text { Immediate } \\
\text { application or } \\
\text { solution } \\
\text { Comp. 8, 5: }\end{array}$ & $\begin{array}{l}\text { - Installation and stabilisation of } \\
\text { organising team for the F:M. } \\
\text { - Installation of a regular co-researching } \\
\text { group at Utopiastadt and in the district. }\end{array}$ & $\begin{array}{l}\text { Practice partners (5), } \\
\text { organising team } \\
\text { Forum:Mirke (5) and } \\
\text { researcher (5) }\end{array}$ & $\begin{array}{l}(+) \text { Outputs so far have been } \\
\text { useful for the practice } \\
\text { partner. } \\
(+) \text { The regular co- }\end{array}$ \\
\hline
\end{tabular}




\begin{tabular}{r|l}
\hline $\begin{array}{r}\text { empowerment and } \\
\text { capacity building }\end{array}$ & $\begin{array}{l}\text { During one year, more than } 10 \text { theses } \\
\text { could be conducted and accompanied. } \\
\text { \& td collaboration }\end{array}$ \\
$\begin{array}{l}\text { Outputs and outcomes are used by } \\
\text { Utopiastadt and the Forum:Mirke to steer } \\
\text { their activities. }\end{array}$
\end{tabular}

researching group concretely helps students organise their inter- or transdisciplinary work.

\section{Co-evaluation not yet started}

The concrete project in district Mirke had started before the heuristic flowchart was finished. Therefore, the process had to be adapted in the course of time. The biggest deviations from the proposed flowchart process could be found in the phases of problem definition and systems analysis, leading to a lack of guidance through the co-production phase activities. Table 3 showed that leadership and decision making was in general carried out jointly by the practice partners and the researcher. In some cases, either practice or science showed stronger involvement. This was due to particular competencies and jointly agreed on. The scientific engagement has been generally appreciated by the practitioners. Especially the ongoing reflection sessions and the openness of the research side to new ideas were highlighted (see also Rose et al. in this volume).

\section{Discussion}

In this article, we addressed two research questions: First, which key components can be derived from both the current RWL discourse and similar, yet more elaborated research approaches? Second, how can these key components be transferred into a comprehensive research practice?

To answer the first research question, we reviewed existing RWL definitions and understandings as well as RWL-related approaches for collaborative, intervention-oriented research. This included transition management, transdisciplinary process models, intervention research, urban living labs and action research.

As key results to the first question, we proposed eight key components for RWL projects: 1) Normative framing: aiming to contribute to sustainable development, 2) Production of systems, target and transformation knowledge (mostly contextualised), 3) Real-world problems as a starting point, 4) Boundaries: "Laboratory" demarcations, defined by content and space, 5) Transdisciplinary collaboration (co-leadership) with clear roles for practice and science, 6) Real-world intervention (often called "experimentation"), 7) Cyclical learning processes through reflection and variation and 8) Empowerment of change agents and capacity building.

Building on this and in regard of the second question, we constructed a cyclical concept (flowchart) for establishing and running a RWL. The concept consists of three phases: co-design, co-production and co-evaluation. It strongly builds on concepts of transdisciplinary science-practice interaction in the phases of co-design and co-evaluation. A cyclical phase of intervention/real-world "experimentation", reflection and learning is integrated in the core phase of co-production.

Finally, we illustrated the key components and the flowchart of a RWL using the case Mirke in the ongoing project "Well-being Transformation Wuppertal". 
Key learnings for setting up a RWL include the following points. First, a strong TD collaboration and co-leadership between science and practice appears as a main pillar of a successful RWL. Through this, sustainable real-world solutions and innovation as well as scientifical output is generated. Second, we do not see scenarios and/or system models as main outputs of the research process. We nevertheless practically saw that a sound systems understanding is helpful for designing appropriate interventions. Third, practical experiences with the RWL approach suggest that more than the average 2-3 years for publicly funded projects is needed in order generate profound systems, target and transformation knowledge. Fourth, the possibility of generalising results of RWL processes appears challenging. More transformative research projects and their results should be thoroughly examined concerning their potential and actual transferability .

Two cross-cutting issues for developing RWLs as a comprehensive research practice are left for more in-depth discussion. The first concerns the conceptualisation and actual performance of researcher's and practitioner's roles and respective contexts. Clarification of roles in RWL processes are frequently asked for which suggests that this is still a needful discussion. The second concerns the necessity and availability of a theory of change (ToC) to embed RWLs in. This could for example help establish effective links between a systems model, ideas for intervention and the intervention itself.

\section{Researcher's and practitioner's context and roles}

Diverse research aspects of RWLs stress the importance of reflection on the researchers' contexts, as this influences how they deal with a potentially demanding situation. Researchers often act as process facilitators, while also enriching the RWL as scientific experts. In doing so, they gain insights and information but are still not directly affected. As Lerchster (2012, p. 59) emphasises in the context of intervention research, this situation allows researchers to be distant and at the same time to have an appropriate empathy for the problem context. It is questionable, whether researchers can meet the requirements for co-facilitating the design process and at the same time fulfil the ideal of a researcher as a reflexive external evaluator. Further discussion on an ideal research context that aims to support the researcher in highly demanding situations with conflicting role expectations is needed. This could for example include regular reflection sessions, supervision, timing of academic responsibilities, tools to capture information and observation protocols. In general, the role of researchers as change agents for sustainability transitions is still discussed and needs a high amount of reflexivity, self-inquiry (Wittmayer et al., 2013, p. 6ff) and transparency.

Reflections of the practitioner's context encompass the following points: Given that experiments always carry the risk of failure (Nevens et al., 2013, p. 114f), the practitioner's institutional setting is essential. Whether it is an honorary association, a municipal institution, an agency depending on funding, or an enterprise influences the level of resources the practitioner is able and/or willing to invest (see also Rose et al. in this volume). Besides the institutional question, the personal context is interesting. The main practitioner, especially if understood as a change agent, has often already reached a high level of innovative power, communication skills and social capital. This might be helpful for fruitful knowledge integration but entails the risk of disregarding several other perspectives, e.g. that of marginalised groups. As practitioners in RWLs mainly work in a niche, science-practice collaborations might empower participating practitioners, which might even lead to a shift in societal "power asymmetries" (Schneidewind et al., 2016, p. 6). A RWL concept therefore 
has to bear in mind the paradoxical structure of empowerment, which can lead to dependence or to the disempowerment of others (Avelino, 2011, p. 78).

\section{Theories of change}

The need for a theory of change (ToC) for targeted interventions must be discussed. A theory of change is, put simply, a theory of how and why a certain intervention will be successful. Existing examples include a wide range. There are macro-level systematisations like the multi-level perspective (Geels, 2002) or the idea of three types/schools of change agents (Schneidewind \& Augenstein, 2016). Meso-level concepts focus on collective change processes in organisations. Microlevel individual and psychological theories try to explain how to support behavioural change, e. g. with the trans-theoretical model by Prochaska and DiClemente (2005).

RWLs and other real-world interventions or "experiments" rarely use theory-driven or tested ToCs, although comprehensible handbooks for the successful design of societal change processes have been published (e.g. Kristof, 2010b). We assume that interventions could greatly benefit from using a tested ToC, but are sceptical of the practical usefulness of specified ToCs for highly contextualised complex settings and problems. We therefore encourage the reflection and testing of ToCs in RWLS (cf. Schäpke, Stelzer, Bergmann, Lang, et al., 2017).

\section{Conclusion}

In this article we presented our understanding of a RWL research practice (key components and flowchart) and illustrated the RWL project in district Mirke.

With both the key components and the cyclical concept for implementing RWL projects we want to stress that RWLs benefit from existing knowledge. Much can be learnt from TD-processes, action and intervention research and the recently growing experience of living labs and transition managementinspired transformation labs. RWLs therefore can be regarded as a member of the family of transformative research concepts. Together with transformative education and institutional change, they form part of a "transformative science" (Schneidewind et al., 2016) that actively engages in sustainable development. We encourage the application of the flowchart and included key components and invite critical reflections and empirical testing.

\section{Acknowledgements}

The authors wish to thank Uwe Schneidewind and Maria Behrens for their helpful comments on previous versions of this article. We are also grateful for valuable comments from our (supervising) colleagues within the research project "Well-being Transformation Wuppertal" Oscar Reutter, Philipp Schepelmann, Hans Haake, Katharina Schleicher and Katrin Maibaum. Furthermore, we want to thank Leonie Büttner for her helpful assistance. Special thanks to the organisers and participants of two international conferences: the "Transformative Research and Development in Urban and Regional Environment Conference" 2016 in Bozen-Bolzano and the "International Sustainability Transitions Conference" 2016 in Wuppertal. The final version also benefitted highly from constructive critique from Roland Scholz, Daniel Lang, Ulli Vilsmaier and three anonymous reviewers. 
This work was supported by the German Federal Ministry of Education and Research (BMBF) under Grant Research for Sustainable Development (FONA), award number 01UT1412A.

\section{Literature}

Abson, D. J., Fischer, J., Leventon, J., Newig, J., Schomerus, T., Vilsmaier, U., ... Lang, D. J. (2017). Leverage points for sustainability transformation. Ambio, 46(1), 30-39. https://doi.org/10.1007/s13280-016-0800-y

Avelino, F. (2011). Power in transition: empowering discourses on sustainability transitions (PhD-Thesis). DRIFT, Erasmus University Rotterdam, Rotterdam.

Beecroft, R., \& Parodi, O. (2016). Reallabore als Orte der Nachhaltigkeitsforschung und Transformation. Technikfolgenabschätzung - Theorie und Praxis, 25(3), 4-8.

Bergmann, M. (2010). Methoden transdisziplinärer Forschung: ein Überblick mit Anwendungsbeispielen. Frankfurt am Main; New York: Campus Verlag.

Bergmann, M., Brohmann, B., Hoffmann, E., Loibl, M. C., Rehaag, R., Schramm, E., \& Voß, J.-P. (2005). Qualitätskriterien transdisziplinärer Forschung. Ein Leitfaden für die formative Evaluation von Forschungsprojekten. Frankfurt am Main: ISOE-Studientexte Nr. 13.

Berkhout, F., Verbong, G., Wieczorek, A. J., Raven, R., Lebel, L., \& Bai, X. (2010). Sustainability experiments in Asia: innovations shaping alternative development pathways? Environmental Science \& Policy, 13(4), 261-271. https://doi.org/10.1016/j.envsci.2010.03.010

Binder, C. R., Absenger-Helmli, I., \& Schilling, T. (2015). The reality of transdisciplinarity: a framework-based self-reflection from science and practice leaders. Sustainability Science, 10(4), 545-562. https://doi.org/10.1007/s1 1625-015-0328-2

Blikstein, P., \& Krannich, D. (2013). The makers' movement and FabLabs in education: experiences, technologies, and research. In Proceedings of the 12th International Conference on Interaction Design and Children (pp. 613-616). New York, NY: ACM Press. https://doi.org/10.1145/2485760.2485884

Bornmann, L. (2013). What is societal impact of research and how can it be assessed? A literature survey. Journal of the American Society for Information Science and Technology, 64(2), $217-233$. https://doi.org/10.1002/asi.22803

Caniglia, G., Schäpke, N., Lang, D. J., Abson, D. J., Luederitz, C., Wiek, A., ... von Wehrden, H. (2017). Experiments and evidence in sustainability science: a typology. Journal of Cleaner Production.

Carew, A. L., \& Wickson, F. (2010). The TD wheel: a heuristic to shape, support and evaluate transdisciplinary research. Futures, 42(10), 1146-1155. https://doi.org/10.1016/j.futures.2010.04.025

De Flander, K., Hahne, U., Kegler, H., Lang, D., Lucas, R., Schneidewind, U., ... Wiek, A. (2014). Resilience and real-life laboratories as key concepts for urban transition research. GAIA - Ecological Perspectives for Science and Society, 23(3), 284-286. https://doi.org/10.14512/gaia.23.3.19

Donovan, C., \& Hanney, S. (2011). The 'Payback Framework' explained. Research Evaluation, 20(3), 181-183. https://doi.org/10.3152/095820211X13118583635756

Erawatch Network ASBL. (2013). A guidebook to assessing environmental impacts of research and innovation policy. Brüssel: Erawatch Network ASBL.

Feola, G., \& Nunes, R. (2014). Success and failure of grassroots innovations for addressing climate change: the case of the transition movement. Global Environmental Change, 24, 232-250. https://doi.org/10.1016/j.gloenvcha.2013.11.011

Geels, F. W. (2002). Technological transitions as evolutionary reconfiguration processes: a multi-level perspective and a case-study. Research Policy, 31(8-9), 1257-1274. https://doi.org/10.1016/S00487333(02)00062-8

Geels, F. W., \& Schot, J. (2007). Typology of sociotechnical transition pathways. Research Policy, 36(3), 399417. https://doi.org/10.1016/j.respol.2007.01.003

Geibler, J. von, Erdmann, L., Liedtke, C., Rohn, H., Stabe, M., Berner, S., ... Schnalzer, K. (2013). Living Labs für nachhaltige Entwicklung: Potenziale einer Forschungsinfrastruktur zur Nutzerintegration in der Entwicklung von Produkten und Dienstleistungen. Wuppertal: Wuppertal-Inst. für Klima, Umwelt, Energie.

Gershenfeld, N. (2012). How to make almost anything: the digital fabrication revolution. Foreign Affairs, 91(6), 43-57. 
Gibbons, M., Limoges, C., Nowotny, H., Schwartzman, S., Scott, P., \& Trow, M. (1994). The new production of knowledge: the dynamics of science and research in contemporary societies. London: Sage Publications.

Gross, M., Hoffmann-Riem, H., \& Krohn, W. (2005). Realexperimente: ökologische Gestaltungsprozesse in der Wissensgesellschaft. Bielefeld: Transcript.

Guggenheim, M. (2012). Laboratizing and de-laboratizing the world changing sociological concepts for places of knowledge production. History of the Human Sciences, 25(1), 99-118. https://doi.org/10.1177/0952695111422978

Hadorn, G. H., Pohl, C., \& Bammer, G. (2010). Solving problems through transdisciplinary research. In R. Frodeman (Ed.), The Oxford Handbook of Interdisciplinarity (pp. 431-452). Oxford University Press.

Hirsch Hadorn, G., Bradley, D., Pohl, C., Rist, S., \& Wiesmann, U. (2006). Implications of transdisciplinarity for sustainability research. Ecological Economics, 60(1), 119-128. https://doi.org/10.1016/j.ecolecon.2005.12.002

Hübner, R. (2012). Interventionsbegriffe im Vergleich. In L. Krainer \& R. E. Lerchster (Eds.), Interventionsforschung. Band 1. Paradigmen, Methoden, Reflexionen. Wiesbaden: Springer VS.

Jahn, T., Bergmann, M., \& Keil, F. (2012). Transdisciplinarity: between mainstreaming and marginalization. Ecological Economics, 79, 1-10. https://doi.org/10.1016/j.ecolecon.2012.04.017

Jahn, T., \& Keil, F. (2016). Reallabore im Kontext transdisziplinärer Forschung. GAIA - Ecological Perspectives for Science and Society, 25(4), 247-252. https://doi.org/10.14512/gaia.25.4.6

Kemmis, S., \& McTaggart, R. (2000). Participatory action research. In N. K. Denzin \& Y. S. Lincoln (Eds.), Handbook of qualitative research (2nd ed). Thousand Oaks, Calif: Sage Publications.

Kemp, R., \& Loorbach, D. (2006). Transition management: a reflexive governance approach. In J.-P. Voß, D. Bauknecht, \& R. Kemp (Eds.), Reflexive Governance for Sustainable Development (pp. 103-130). Cheltenham, UK : Northampton, MA: Edward Elgar Publishing.

Kemp, R., Schot, J., \& Hoogma, R. (1998). Regime shifts to sustainability through processes of niche formation: the approach of strategic niche management. Technology Analysis \& Strategic Management, 10(2), 175198. https://doi.org/10.1080/09537329808524310

Kohler, R. E. (2008). Lab history: reflections. Isis, 99(4), 761-768. https://doi.org/10.1086/595769

Krainer, L., \& Lerchster, R. (2012a). Interventionsforschung: Paradigmen, Methoden, Reflexionen. In L. Krainer \& R. E. Lerchster (Eds.), Interventionsforschung. Bd. 1: Paradigmen, Methoden, Reflexionen (pp. 9-19). Wiesbaden: Springer Fachmedien Wiesbaden.

Krainer, L., \& Lerchster, R. E. (Eds.). (2012b). Interventionsforschung. Bd. 1: Paradigmen, Methoden, Reflexionen. Wiesbaden: Springer VS.

Kristof, K. (2010a). Models of change: Einführung und Verbreitung sozialer Innovationen und gesellschaftlicher Veränderungen in transdisziplinärer Perspektive. Zürich: vdf-Hochschulverl.

Kristof, K. (2010b). Wege zum Wandel: wie wir gesellschaftliche Veränderungen erfolgreicher gestalten können. München: Oekom.

Lang, D. J., Wiek, A., Bergmann, M., Stauffacher, M., Martens, P., Moll, P., ... Thomas, C. J. (2012). Transdisciplinary research in sustainability science: practice, principles, and challenges. Sustainability Science, 7(S1), 25-43. https://doi.org/10.1007/s11625-011-0149-x

Lerchster, R. E. (2012). Zentrale Grundannahmen der Interventionsforschung. In L. Krainer \& R. E. Lerchster (Eds.), Interventionsforschung. Bd. 1: Paradigmen, Methoden, Reflexionen. Wiesbaden: Springer VS.

Liedtke, C., Baedeker, C., Hasselkuß, M., Rohn, H., \& Grinewitschus, V. (2015). User-integrated innovation in Sustainable LivingLabs: an experimental infrastructure for researching and developing sustainable product service systems. Journal of Cleaner Production, 97, 106-116. https://doi.org/10.1016/j.jclepro.2014.04.070

Löw, M. (2012). Soziologie der Städte (2. Aufl). Frankfurt am Main: Suhrkamp.

Luederitz, C., Schäpke, N., Wiek, A., Lang, D. J., Bergmann, M., Bos, J. J., .. Westley, F. R. (2016). Learning through evaluation - a tentative evaluative scheme for sustainability transition experiments. Journal of Cleaner Production. https://doi.org/10.1016/j.jclepro.2016.09.005

Mauser, W., Klepper, G., Rice, M., Schmalzbauer, B. S., Hackmann, H., Leemans, R., \& Moore, H. (2013). Transdisciplinary global change research: the co-creation of knowledge for sustainability. Current Opinion in Environmental Sustainability, 5(3-4), 420-431. https://doi.org/10.1016/j.cosust.2013.07.001 
Miah, J. H., Griffiths, A., McNeill, R., Poonaji, I., Martin, R., Morse, S., ... Sadhukhan, J. (2015). A small-scale transdisciplinary process to maximising the energy efficiency of food factories: insights and recommendations from the development of a novel heat integration framework. Sustainability Science, 10(4), 621-637. https://doi.org/10.1007/s11625-015-0331-7

Mogalle, M. (2001). Management transdisziplinärer Forschungsprozesse. Basel: Birkhäuser.

Muhar, A., Vilsmaier, U., Glanzer, M., \& Freyer, B. (2006). Initiating transdisciplinarity in academic case study teaching: experiences from a regional development project in Salzburg, Austria. International Journal of Sustainability in Higher Education, 7(3), 293-308. https://doi.org/10.1108/14676370610677856

MWK - Ministerium für Wissenschaft, Forschung und Kunst. (2013). Wissenschaft für Nachhaltigkeit. Herausforderung und Chance für das baden-württembergische Wissenschaftssystem. Stuttgart: MWK.

Nevens, F., Frantzeskaki, N., Gorissen, L., \& Loorbach, D. (2013). Urban transition labs: co-creating transformative action for sustainable cities. Journal of Cleaner Production, 50, 111-122. https://doi.org/10.1016/j.jclepro.2012.12.001

Nowotny, H., Scott, P., \& Gibbons, M. (2001). Re-thinking science: knowledge and the public in an age of uncertainty. Cambridge: Polity Press.

OECD - Organisation for Economic Co-operation and Development. (2010). Guidance on sustainability ompact assessment. Paris: OECD Publishing.

OECD - Organisation for Economic Co-operation and Development. (2015). How's life? 2015: measuring wellbeing. Paris: OECD Publishing.

Ozanne, J. L., \& Saatcioglu, B. (2008). Participatory action research. Journal of Consumer Research, 35(3), 423-439. https://doi.org/10.1086/586911

Palzkill, A., Wanner, M., \& Markscheffel, F. (2015). Suffizienz als Geschäftsmodell: Die Bedeutung von SocialEntrepreneurship-Initiativen am Beispiel von Utopiastadt Wuppertal. uwf UmweltWirtschaftsForum, 23(1-2), 69-76. https://doi.org/10.1007/s00550-015-0353-8

Parodi, O., Albiez, M., Beecroft, R., Meyer-Soylu, S., Quint, A., Seebacher, A., ... Waitz, C. (2016). Das Konzept „Reallabor“ schärfen. Ein Zwischenruf des Reallabor131: KIT findet Stadt. GAIA, 25(4), 284285.

Penfield, T., Baker, M. J., Scoble, R., \& Wykes, M. C. (2014). Assessment, evaluations, and definitions of research impact: a review. Research Evaluation, 23(1), 21-32. https://doi.org/10.1093/reseval/rvt021

Pohl, C., \& Hirsch Hadorn, G. (2008). Methodological challenges of transdisciplinary research. Natures Sciences Sociétés, 16(2), 111-121. https://doi.org/10.1051/nss:2008035

Prochaska, J. O., \& DiClemente, C. C. (2005). The transtheoretical approach. In J. C. Norcross \& M. R. Goldfried (Eds.), Handbook of psychotherapy integration (2nd ed, pp. 147-171). New York: Oxford University Press.

Przyborski, A., \& Wohlrab-Sahr, M. (2014). Qualitative Sozialforschung: ein Arbeitsbuch (4., Aufl). München: Oldenbourg.

Raskin, P., Banuri, T., Gallopín, G., Gutman, P., Hammond, A., Kates, R., \& Swart, R. (2002). Great transition: the promise and lure of the times ahead. Boston: Stockholm Environment Institute.

Reid, W. V., Chen, D., Goldfarb, L., Hackmann, H., Lee, Y. T., Mokhele, K., ... Whyte, A. (2010). Earth system science for global sustainability: grand challenges. Science(Washington), 330(6006), 916-917. https://doi.org/10.1126/science.1196263

Roux, D. J., Stirzaker, R. J., Breen, C. M., Lefroy, E. C., \& Cresswell, H. P. (2010). Framework for participative reflection on the accomplishment of transdisciplinary research programs. Environmental Science \& Policy, 13(8), 733-741. https://doi.org/10.1016/j.envsci.2010.08.002

Rückert-John, J. (2013). Die Nachhaltigkeit der Debatte um soziale Innovationen - Innovationsschub für den nachhaltigen Wandel. In J. Rückert-John (Ed.), Soziale Innovation und Nachhaltigkeit (pp. 289-307). Wiesbaden: Springer Fachmedien Wiesbaden.

Schäpke, N., Singer-Brodowski, M., Stelzer, F., Bergmann, M., \& Lang, D. J. (2015a). Creating space for change: sustainability transformations: the case of Baden-Württemberg. GAIA - Ecological Perspectives for Science and Society, 24(4), 281-283. https://doi.org/10.14512/gaia.24.4.17

Schäpke, N., Singer-Brodowski, M., Stelzer, F., Bergmann, M., \& Lang, D. J. (2015b). Creating space for change: sustainability transformations: the case of Baden-Württemberg. GAIA - Ecological Perspectives for Science and Society, 24(4), 281-283. https://doi.org/10.14512/gaia.24.4.17 
Schäpke, N., Stelzer, F., Bergmann, M., \& Lang, D. J. (2016). Tentative theses on transformative research in real-world laboratories. First insights from the accompanying research ForReal. TATuP Technikfolgenabschätzung - Theorie Und Praxis, 25(3), 45-51.

Schäpke, N., Stelzer, F., Bergmann, M., Lang, D. J., Wagner, F., \& Miller, E. (2017). Real-world Laboratories and Transformation Research: Call for Papers: GAIA Open Access Special Issue. GAIA - Ecological Perspectives for Science and Society, 26(1), 55-57. https://doi.org/10.14512/gaia.26.1.12

Schäpke, N., Stelzer, F., Bergmann, M., Singer-Brodowski, M., Wanner, M., Caniglia, G., \& Lang, D. (2017). Reallabore im Kontext transformativer Forschung. Ansatzpunkte zur Konzeption und Einbettung in den internationalen Forschungsstand (IETSR Discussion Papers). Lüneburg: Leuphana Universität.

Schneidewind, U. (2014). Urbane Reallabore - ein Blick in die aktuelle Forschungswerkstatt. Pnd Online, (3), $1-7$.

Schneidewind, U., \& Augenstein, K. (2016). Three schools of transformation thinking: the impact of ideas, institutions, and technological innovation on transformation processes. GAIA - Ecological Perspectives for Science and Society, 25(2), 88-93. https://doi.org/10.14512/gaia.25.2.7

Schneidewind, U., \& Scheck, H. (2013). Die Stadt als „Reallabor“ für Systeminnovationen. In J. Rückert-John (Ed.), Soziale Innovation und Nachhaltigkeit (pp. 229-248). Wiesbaden: Springer Fachmedien.

Schneidewind, U., \& Singer-Brodowski, M. (2013). Transformative Wissenschaft: Klimawandel im deutschen Wissenschafts- und Hochschulsystem. Marburg: Metropolis Verlag.

Schneidewind, U., Singer-Brodowski, M., Augenstein, K., \& Stelzer, F. (2016). Pledge for a transformative science. A conceptual framework (Wuppertal Paper No. 191). Wuppertal: Wuppertal Institute for Climate, Environment and Energy.

Scholz, R. W. (2011). Environmental literacy in science and society: from knowledge to decisions. Cambridge ; New York: Cambridge University Press.

Scholz, R. W., Lang, D. J., Wiek, A., Walter, A. I., \& Stauffacher, M. (2006). Transdisciplinary case studies as a means of sustainability learning: Historical framework and theory. International Journal of Sustainability in Higher Education, 7(3), 226-251. https://doi.org/10.1108/14676370610677829

Scholz, R. W., \& Steiner, G. (2015a). The real type and ideal type of transdisciplinary processes: part II-what constraints and obstacles do we meet in practice? Sustainability Science, 10(4), 653-671. https://doi.org/10.1007/s11625-015-0327-3

Scholz, R. W., \& Steiner, G. (2015b). The real type and ideal type of transdisciplinary processes: part Itheoretical foundations. Sustainability Science, 10(4), 527-544. https://doi.org/10.1007/s11625-015-03264

Scholz, R. W., \& Steiner, G. (2015c). Transdisciplinarity at the crossroads. Sustainability Science, 10(4), 521526. https://doi.org/10.1007/s11625-015-0338-0

Scholz, R. W., \& Tietje, O. (2002). Embedded case study methods: integrating quantitative and qualitative knowledge. Thousand Oaks, Calif: Sage Publications.

Seyfang, G., \& Haxeltine, A. (2012). Growing grassroots innovations: exploring the role of community-based initiatives in governing sustainable energy transitions. Environment and Planning C: Government and Policy, 30(3), 381-400. https://doi.org/10.1068/c10222

Seyfang, G., \& Smith, A. (2006). Community action: a neglected site of innovation for sustainable development? Working Paper - Centre for Social and Economic Research on the Global Environment, (1), 1-25.

Spaapen, J., \& van Drooge, L. (2011). Introducing 'productive interactions' in social impact assessment. Research Evaluation, 20(3), 211-218. https://doi.org/10.3152/095820211X12941371876742

Stadt Wuppertal. (2014). Stadtumbau-West. Städtebauliches Entwicklungskonzept Wuppertal. Sanierungsgebiet Elberfelder Nordstadt/Arrenberg. Fortschreibung des Integrierten Handlungsprogramms für die Bereiche 'Mirker Quartier' und 'Südstraße'. Wuppertal: Stadt Wuppertal Stadtentwicklung. Retrieved from http://www.wuppertal.de/rathaus/onlinedienste/ris/getfile.php?id=171768\&type=do

van den Bosch, S. (2010). Transition experiments: exploring societal changes towards sustainability. Rotterdam: DRIFT, Erasmus University Rotterdam.

Vilsmaier, U., Engbers, M., Luthardt, P., Maas-Deipenbrock, R. M., Wunderlich, S., \& Scholz, R. W. (2015). Case-based mutual learning sessions: knowledge integration and transfer in transdisciplinary processes. Sustainability Science, 10(4), 563-580. https://doi.org/10.1007/s11625-015-0335-3

von Unger, H. (2014). Partizipative Forschung. Wiesbaden: Springer Fachmedien Wiesbaden. 
Wagner, F., \& Ertner, S. (2016). Reallabore für nachhaltiges Wissen - Forschung für und mit Zukunft. GAIA Ecological Perspectives for Science and Society, 25(1), 57-58. https://doi.org/10.14512/gaia.25.1.12

Wagner, F., \& Grunwald, A. (2015). Reallabore als Forschungs- und Transformationsinstrument. Die Quadratur des hermeneutischen Zirkels. GAIA - Ecological Perspectives for Science and Society, 24(1), $26-31$. https://doi.org/10.14512/gaia.24.1.7

Walter, A. I., Helgenberger, S., Wiek, A., \& Scholz, R. W. (2007). Measuring societal effects of transdisciplinary research projects: design and application of an evaluation method. Evaluation and Program Planning, 30(4), 325-338. https://doi.org/10.1016/j.evalprogplan.2007.08.002

WBGU - German Advisory Council on Global Change. (2011). World in transition: a social contract for sustainability. Berlin: WBGU.

WBGU - German Advisory Council on Global Change. (2014). Climate protection as a world citizen movement: special report. Berlin: WBGU.

WBGU - German Advisory Council on Global Change. (2016). Humanity on the move: unlocking the transformative power of cities. Berlin: WBGU.

Wieczorek, A. J., Raven, R., \& Berkhout, F. (2015). Transnational linkages in sustainability experiments: a typology and the case of solar photovoltaic energy in India. Environmental Innovation and Societal Transitions, 17, 149-165. https://doi.org/10.1016/j.eist.2015.01.001

Wiek, A., \& Lang, D. J. (2016). Transformational Sustainability Research Methodology. In H. Heinrichs, P. Martens, G. Michelsen, \& A. Wiek (Eds.), Sustainability Science (pp. 31-41). Dordrecht: Springer Netherlands. Retrieved from http://link.springer.com/10.1007/978-94-017-7242-6_3

Wiek, A., Talwar, S., O'Shea, M., \& Robinson, J. (2014). Toward a methodological scheme for capturing societal effects of participatory sustainability research. Research Evaluation, 23(2), 117-132. https://doi.org/10.1093/reseval/rvt031

Wittmayer, J., Roorda, C., \& Steenbergen, F. van. (2014). Governing urban sustainability transitions - inspiring examples. Rotterdam: DRIFT, Erasmus University Rotterdam.

Wittmayer, J., \& Schäpke, N. (2014). Action, research and participation: roles of researchers in sustainability transitions. Sustainability Science, 9(4), 483-496. https://doi.org/10.1007/s11625-014-0258-4

Wittmayer, J., Schäpke, N., Feiner, G., Piotrowski, R., van Steenbergen, F., \& Baasch, S. (2013). Action research for sustainability reflections on transition management in practice. Berlin: Ecologic Insitute.

Wolf, B., Lindenthal, T., Szerencsits, M., Holbrook, J. B., \& Heß, J. (2013). Evaluation research beyond scientific impact. GAIA - Ecological Perspectives for Science and Society, 22(2), 104-114. 